\title{
Pillanatképek a 150 éves állami tanítóképzésről - a „budai képző” emlékei
}

\section{Demeter Katalin}

ELTE Eötvös Lóránd Tudományegyetem Tanító- és Óvóképző Kar, főiskolai tanár, e-mail: demeter.katalin@tok.elte.hu

ORCID : 0000-0001-7209-1026

Eötvös fózsef vallás- és közoktatásügyi miniszter kezdeményezésére 1869 őszén kezdte meg müködését az első magyar állami tanitóképző intézet: a „Budai Képzo””, az ELTE Tanitó- és Óvóképző Karának elődintézménye. A Budai Képző fennállásának 150 éve alatt az összegyüjtött dokumentumok, albumok, évkönyvek, sajtómegjelenések képei, fényképei ünnepi pillanatokat, mozgalmas mindennapokat, jeles tanárokat, jellemzö helyszineket rögzitettek. A régi újságoldalak, kéziratok, nyomtatványok és az egyre sokasodó képek hosszú sorának áttekintése azt látszik megerősiteni, hogy a hirdetett jelszavak, külsőségek, jelképek változásai nem renditették meg a tanítóképzés Eötvös fózsef által megfogalmazott alapvetését. A Budai Képző a hatalmi viszonyok változásai közepette mindvégig megbecsülte hagyományait, nagy tudású tanárainak munkáját, otthont adott a müvészeteknek, a kultúrának, és élére állt a tanítóképzés megújításának.

Kulcsszavak: állami tanítóképzés, Budai Képző, Eötvös József, emlékképek, hagyományok, megújítás, megbecsülés

DOI: 10.37205/TEL-hun.2019.ksz.08

\section{Az út és az elvek - változás és állandóság a Budai Képzőben}

Az évforduló emlékezésre szólít, jeles kortársaink müveinek olvasására, akik az állami tanítóképzés - és részeként a Budai Képző - történetének szerzői és szereplői is. (Bollókné \& Kelemen, 1996; Donáth, 2008; Hunyadyné, 2012; Márkus \& M. Pintér 2019) Az emlékezés részeként kezdtünk hozzá a hosszú idő alatt összegyült képek, dokumentumok válogatásához és a „képolvasáshoz”, szem előtt tartva, hogy az ókori szerző szállóigévé lett gondolata: „Pro captu lectoris habent sua fata libelli” ${ }^{3}$ - képekre is alkalmazható (Belting, 2003; Visy, 2017).

A 150. évfordulóját ünneplő állami tanítóképző egyetlen elődjének sem volt hivatalos neve „Budai Képzo”, mégis így maradt meg sokak emlékezetében, hiszen az intézmény eredendő hivatásához, a tanítóképzéshez társultak ugyan időről idő-

\footnotetext{
${ }^{3}$ Terentianus Maurus De litteris syllabis pedibus et metris. 1286. sor
} 
re újabb területek, ezek azonban főként a pedagógusképzés palettájának bővülését jelentették, müködésének központi helyszíne pedig mindvégig Buda maradt. Az állami tanítóképzéshez egykor a polgári iskolai és a tanítóképző-intézeti tanárképzés csatlakozott, majd a nemzetiségi pedagógusképzés, a rajz- és az énektanárok részképzése, a múlt század hatvanas éveinek végétől az óvóképzés, az ezredforduló időszakában néhány évig határterületi rokonszakok, a legutóbbi időben pedig az egyetemi szintű csecsemő- és kisgyermekvelő, valamint a rajz- és vizuáliskultúra tanárképzés (Panyik, 1991; Donáth, 1998; Kelemen, 2007; Márkus, 2017).

A tanítóképzés időtartamának és szintjének emelése az állami képzés története során mindvégig kiemelt célja volt a tanítói hivatással foglalkozók fejlesztő törekvéseinek. A képzés szerkezeti változásaitól az eredményesség fokozása mellett a tanítói munka presztízsének növekedését remélték. A társadalmi igényekkel és az iskoláztatás általános fejlődésével hol lassabban, hol gyorsabban lépést tartva, időről időre sikerült elérni mind a képzési időtartam, mind pedig a képzési szint emelését. A törvénnyel szabályozott képzés kezdeteitől középfokú, képesítő vizsgával záruló, növekvő időtartamú intézeti tanítóképzéstől az érettségit adó középiskolai, 1959-től az érettségire épülő, hároméves felsőfokú tanítóképzésen át az 1975-től hároméves, majd 1994-től az első hat iskolaév nevelőmunkájára felkészítő, négyéves föiskolai tanítóképzésig vezetett ez az út. A Budai Képző mindvégig meghatározó szerepet játszott a tanítóképzés szerkezetének megújítási mozgalmaiban (Hunyadyné, 2012; Kelemen, 2012; Donáth, 2015).

A képekből és dokumentumokból kirajzolódik az iskoláztatás és a képzés társadalmi-történeti beágyazottsága, a „változó időhöz” való önkéntes vagy kényszerủ alkalmazkodás, ami megmutatkozik az állami tanítóképzés 150 éves története során a hirdetett jelszavak, a külsőségek, jelképek változásában is. Kevéssé változott azonban a hullámzó felszín alatt a tanítóképzés elvi alapvetése, ezt a különböző időkben született és követett alapelvek szövegei példázhatják.

Eötvös József az állami tanítóképzők állítását eloóró népoktatási törvény elfogadását megelőzően naplójában így fogalmazta meg a követendő oktatáspolitikai alapelveket:

„Az állam nem vállalhatja magára a kötelezettséget, hogy a polgároknak az anyagi s szellemi javakat megszerezze; feladása csak az, hogy e javak megszerzését az egyeseknek lehetővé tegye. [...] Nagy államainkban a centralizáció, mint másban, úgy a nevelésben, kivihetetlen és káros, s egyedüli eredménye csak az le- 
het, hogy az állam hatalma a legfontosabb érdekek feláldozásával növeltessék. Az állam feladása a nevelés dolgában, mint mindenben, biztosítani az egyéni szabadságot, de biztosítani azt mindenkinek, a legszegényebbnek szintúgy, mint a gazdagoknak." (Eötvös, 1853/1977, p. 409).

A magyar királyi állami elemi tanítóképezdék tantervéről 1882-ben közreadott rendelet így szól a képzés céljáról:

„A tanítóképző intézetek célja hivatásuk iránt lelkesülő, foglalatosságaikban jártas, oly munkás es ügyes tanítókat képezni, kik az emberiség szeretetének érzésétől áthatva, alapos ismereteik segítségével es kiváltképpen jó példaadással vezessék a gondviselésükre bízott növendékeket: önmunkásságra, az ismeretek gyüjtésére, az erkölcsi nemesb érzésre és általában a felvilágosodásra." (Szakál, 1934, p. 70).

A tanterv szerint a növendékek tanításában és nevelésében hármas célt kell elérni: 1. önzéstelen emberszeretetet, 2. a szükséges tudományokat és azok tanítási módját és 3. szellemi és testi ügyességet. A Budai Képző fennállásának százéves, a tanító- és óvóképzés felsőfokúvá válásának tízéves évfordulóján, 1969-ben az intézményt 25 éven át vezető Békési Lajos főigazgató tartott ünnepi beszédet. Ebből is tanulságos idéznünk, mert a múlt század közepétől négy évtizeden át tartó korszak rég letűnt jelképei alatt elhangzott mondatokból is a megőrzött alapvetés rajzolódik ki:

„A századfordulóig intézetünk 1800, 1900-tól a felszabadulásig pedig közel 2000 tanítót adott az országnak. Nehéz lenne számszerủen megmutatni, hány ezer gyermeket nevelt értelmes, jellemes fiatallá. Hány ezer ifjú és felnőtt köszönhette ennek a 4000 tanítónak szélesebb látókörét, szemlélete gazdagodását, humanitása kibontakozását." (Nábrádi, 1970, p. 7).

A Budai Képző múltját méltatva kiemelte a jól képzett elődök odaadó munkáját, akik mind elméleti érdeklődésük, tárgybeli felkészültségük, mind pedig a nevelésügy országos gondjainak megoldásában való részvételük terén példaként állhatnak a jubiláló utódok előtt, mint Gyertyánffy István, Kiss Áron, Drozdy Gyula, Quint József, Sztankó Béla is. A Budai Képző fennállásának 130. évfordulóján, az egyetemi integráció küszöbén Kelemen Elemér fóigazgató szavai - méltatva az elvégzett munkát és a kiemelkedő elődöket - az új követelményeknek megfelelő céltudatosságra szólítottak.

„Az elmúlt százharminc év története vagy éppen az utolsó negyvené, a magyar tanítóképzés és intézményünk múltja sok-sok szakmai tapasztalatot, kimeríthetet- 
len erkölcsi tartalékot és a nagyszerü emberi példák sorát kínálja számunkra az el nem kerülhető jövő tudatos alakításához s a kor által reánk parancsolt megújuláshoz." (Kelemen, 1999, p. 17).

A felsőoktatási expanzió az ezredforduló időszakában világszerte átszervezésekhez vezetett, a hazai oktatáspolitika irányítói a szervezeti centralizációval járó integrációt választották a feltételek megteremtésének megoldására. Az állami tanítóképzés Budapesten 2000-től tudományegyetemi keretek között, 2006-tól az Európai Felsőoktatási Térségbe illeszkedő alapképzésként folyik. A Budai Képző utódintézménye a jubileumi évfordulón az Eötvös Loránd Tudományegyetem Tanító- és Óvóképző Kara (Bollókné \& Hunyadyné, 2003; Kelemen, 2007; Kováts \& Temesi, 2018).

\section{A tanítók és képzésük helyzetéről}

A 19. század első felében sorra alakultak az oktatásügy fejlődésére, a tanítók érdekeinek képviseletére szövetkező tanítószervezetek, erről tájékoztat egyebek között a Nevelési Emléklapok kiadványsorozata is. Az 1848 szeptemberében megjelent, hatodik füzetben a szerkesztő, Tavasi Lajos beszámol a magyar tanítók első egyetemes, azaz a felekezetközi gyűléséről. A gyülés javaslatot tett a hazai tanügy törvényi szabályozására:

„Mely törvények azonban csak az anyagi és a tanodának külső szerkezeti körét érintsék, ellenben a tan- és nevelésszabadságot, mi az ügynek belső leheletét teszi, a tudományi, emberészeti és hazai közszellem hatalmas kifejlődésére bízzák. Hogy tekintetbe vétessék a magyarnak és embernek nevelendő egyén, a szüle és a tanító." (Tavasi, 1848, p. IV).

Az Eötvös-törvény sok kérdésben rendezte a tanítók helyzetét, ám a tanítóság szerteágazó érdekei továbbra is életben tartották az eltérő céloknak hangot adó különféle szervezeteket és orgánumaikat. A számos szakmai lap közül a Népnevelők Lapja, amely célja szerint a javakkal kevéssé ellátott nevelők „parányi, és többnyire szegény" közönségének az iskolaügyre vonatkozó nézeteit adta közre, bizonyult hosszabb időn át életképesnek: 1863 és 1918 között adták ki. Az 1868-ban indult, kezdetben hét nyelven megjelenő Néptanítók Lapját állami orgánumként hozta létre Eötvös József minisztériuma, a csaknem tizenötezer példányban nyomtatott kiadványt minden tanító ingyen kapta meg, kezdetben valóban az általa megjelölt nemzetiségi nyelven, később azonban már csak magyarul. A Néptanítók Lapjáról, aminek második szerkesztője a Budai Képzőt igazgató Gyertyánffy 
István volt, az 1873-ban rendezett bécsi világkiállítás is megemlékezett (Ferenczi, 1903).

A budai állami férfiképzőt 1873-tól igazgató Gyertyánffy István sikeres munkája, elismertsége figyelmet irányított az állami tanítóképzés szabályozásának és támogatásának jelentőségére. Az 1854 és 1921 között megjelent, „széles néprétegek” igényes olvasmányául szolgáló képes hetilap, a Vasárnapi Újság Gyertyánffyt méltatva 1882-ben így írt az állami tanítóképzésnek a népoktatásban játszott szerepéről:

„Az emberek közt az egyenlősítést a népnevelés fogja meghozni. Mindehhez azonban erős és szilárd tanítói kar kell. Erős intézmény, erős értelmiséggel. Az intézmény megalkotását Eötvös megkezdte s utódai folytatják. Az állami felügyelet, állami nyugdíj, a tanítói fizetések állami behajtása mind egy-egy lánczszem, mely ez ország tanítóságát összefüzi. Az értelmi színvonal emelése szintén Eötvös eszméi szerint történik." (Vasárnapi Újság, 1881, p. 376).

A Népnevelők Lapjához és az országos tanítógyűlésekhez hasonlóan a szakmai közösség hozta létre - kezdetben Nagy László irányításával - a Magyar Tanítóképző Intézeti Tanárok Országos Egyesületét (TITOE) valamint a Magyar Tanitóképző címü, ötvenhét éven át, egészen 1944-ig megjelent egyesületi folyóiratot. A folyóiratnak egy korszakban székhelyéül a Budai Képző szolgált, tanárai pedig gyakran közremüködtek a lap és az egyesület munkájában (Kelemen, 2004).

A szakmai közösség szerveződéseinek feltámasztására, életben tartására az utóbbi időkben is születtek kezdeményezések. Az Óvó- és Tanítóképzők Egyesülete, az egykori TITOE örököse, a képzők Főigazgatói, majd Dékáni Kollégiuma, az Országos Tantervfejlesztő, majd Programfejlesztő Bizottság egy-egy feladatra az ezredforduló után is felállt, de tagjai a bekövetkezett felsőoktatási integrációk hullámzásai közepette különböző helyzetbe kerültek, ezért a korábbiaknál is nehezebben tudják szakmai kérdésekben álláspontjaikat közösen képviselni.

A tanítók és képzésük megbecsültsége éles megvilágításba helyezi az egyes korszakok viszonyát az Eötvös által megfogalmazott célokhoz. A tanítóképzés jeles személyiségeinek tiszteletére, emlékük őrzésére egykori tanítványaik, tisztelőik alapítványokat létesítettek, az adományozók által juttatott javak módot adnak az arra érdemes jelöltek és oktatóik támogatására, ezzel is emelve a tanítói hivatás megbecsültségét. A képzés fenntartásához érdemben hozzájáruló mecenatúrára azonban ezen - a reklámot, szenzációt aligha biztosító - területen nem lehet számítani. A 21. században a felsőoktatási fejlesztések finanszírozását uniós pályázati 
források segítik, a pedagógusképzés müködtetése azonban ebben a korszakban is az államra hárul, ami folyamatossá tette és teszi a gazdálkodás szűkösségét (Polónyi, 2018).

Akár a Budai Képző évkönyveit lapozzuk, akár az utóbbi évek felméréseinek adataira tekintünk, arra juthatunk, hogy a tanítójelöltek a másfélszáz év minden korszakában jellemzően a magyar társadalom jövedelmi deciliseinek alsó harmadát képviselő családokból származtak, tanulmányaik folytatásához legfeljebb szerény mértékben tudtak hozzájárulni, így nehézségek árán tanultak olyan pályára készülve, amely szűkös megélhetést biztosított. A Budai Képző régi évkönyvei nyilvántartották a képzős növendékek szüleinek foglalkozását. Az 1942. évi adatok szerint például magas jövedelmi kategóriába sorolható foglalkozás nincs a felsoroltak között, a tanítók, önálló gazdálkodók, kereskedők, beosztott tisztviselők is kevesen vannak, a szülők többsége „segédszemély, altiszt” és hasonló, alacsony presztízsű, szerény jövedelmủ csoportba tartozik. „Ma már mindenki menekül a tanári pálya elől és akik a kezdetén vannak, azok is inkább magánvállalatoknál kényszerülnek elhelyezkedni” olvasható a Magyar Tanítóképző 1943-as írásában (Mesterházy, 1943, p. 230). Egy 2015-ben megjelent, kutatásra alapozott hazai tanulmány arról ad számot, hogy a felsőoktatásban „a pedagóguspályát választók mind a kulturális tőke (szülők végzettsége), mind a gazdasági háttér tekintetében kedvezőtlenebb helyzetben vannak a más pályára lépőkhöz képest”, a tanítók pedig a felsorolt értelmiségi pályák között mind a társadalmi, mind az anyagi megbecsültség skálájának legalsó pontjára kerültek (Paksi et al, 2015, p. 40.).

A tanítók megbecsültségével összhangot nem mutató elvárásokról gyakran idézik azt - az először 1892-ben megjelent - szöveget, aminek itt is helye van, mert kiválóan érzékelteti a követelmények túlzásait: ne csak a nép gyermekeinek, hanem magának a népnek is legyenek nevelői, a közegészségügy őrei, a hiányzó orvosok megbízható helyettesítői, legyenek ügyes mezei gazdák, pomológusok [gyümölcstermesztők], méhészek, selyemhernyó-termesztők, értsenek mindenféle háziiparhoz, legyenek a zenét alaposan értő kántorok, akik nemcsak a templomban tudják kötelességüket teljesíteni, hanem tudjanak dalköröket is szervezni és vezetni, tudjanak legalább valamennyit a süketnémák, s a hülyék tanításához, legyenek képesek működésük helyén a tűzoltást szervezni, a tanítónő esetleg lehessen gouvernante, azért tudjon jól franciául, zongorázni stb." (Radó 1892). Ahogyan egykor, úgy azóta is gyakori a túlzó elvárás, jóllehet összetett volt és maradt az a szerep, amire a gyerekek sokszínủ világának megfelelően sokoldalú tanító hiva- 
tott, ebből azonban nem következik, hogy a közösségek életében felmerülő számtalan társadalmi feladattal e hivatás művelőinek kellene egyedül megbirkóznia.

\section{A tanítóknak háza vagyon...*}

Eötvös népoktatási törvénye nagy körültekintéssel rendelkezett a népiskolák és a tanítóképzők épületeiről, kertjeikről, felszereléseikről, így nem csodálható, hogy ezekről számos kép és részletező leírás készült.

1869 novemberében a Budai Állami Tanítóképezde az igazgató mellett öt tanárral és tíz tanítójelölttel megkezdte múködését, decemberben pedig Zirzen Janka vezetésével megnyílt az első állami tanítónőképző is, annak örökségéből került jelenlegi épületünkbe a ma is látható, megszólaltatható folyosói harang (Ember, 1998). Mindkét állami képző szűkös, bérelt helyiségekben kezdte a munkát. A férfiképző az I. kerületben, a Vérmező keleti oldalán nyílt meg, innen 1871-ben a Várban levő Országház utca 14. számú házba költözött (Padányi, 1940, Padányi, 1941).

Az Országház utca északi sarkán álló, harmadik épületet 1873-tól a népiskolai tanítóképző már a polgári iskolai tanítóképzővel együtt használta egészen 1883-ig, itt azonban az internátus nem fért el. A Vasárnapi Újságban megjelent rajz ugyan megszépíti ezeket az épületeket, a leírásból azonban kitűnik a várbeli elhelyezés alkalmatlansága: „talán rá kerül majd a sor, hogy uj és czélszerü épületet nyerjen a népnevelés egyik főintézete is. Ez az intézet szűk, s a levegő benne rossz, ujabban meg a nedves időjárás alatt beázott." (Vasárnapi Újság, 1881, p. 376).

A negyedik helyszín az I. kerületi Győri-út 13-15. számú ház volt, itt 1883-tól múködött a tanítóképző és internátusa, a polgári iskolai tanárképzővel és - 1887től - a tanítóképző intézeti tanárok képzésével összevont, Paedagogiumnak nevezett intézmény keretében. A jelöltek gyakorlata számára népiskola és polgári iskola is rendelkezésre állt. Ez az épület a képek bizonysága szerint méltó körülményeket teremtett a munkához: orgonát és zongorát látunk az elegánsan berendezett nagyteremben, korszerűen felszerelt természettudományi tanterem is szolgálta a tanítást. A Néptanítók Lapjában Kiss Áron, a későbbi igazgató tudósított arról, hogy I. Ferenc József király 1886. május 9-én látogatást tett a Győri úti képezdében, ahol Gyertyánffy igazgató és Trefort miniszter a tanárok társaságában fogadta az uralkodót, aki bizonyára mindennel meg lehetett elégedve (Kiss Áron, 1886).

${ }^{4}$ Arany János „dac-versének” sorában a Tudomány házáról esik szó... 
Berzeviczy Albert az Osztrák-Magyar Monarchiát jellemző 21 részes történeti könyvsorozat Budapestről szóló kötetében elismeréssel számolt be arról, hogy az egyesült fơváros első tizenhat évében az elemi iskolai tantermek és az iskolába járó gyermekek száma is csaknem kétszeresére nőtt, az iskolaügy alapozását szolgáló kisdedóvás egyesületi és magánfenntartású intézményei is gyarapodtak. A fôvárostól kapott telken, a Rózsák terén épült fel az országos kisdedóvó egyesület óvóképző intézete internátussal és mintaóvodával. Kiemelten szólt a fơvárosi tanítóképzésről, különösen a Győri úti képzőről:

„A magyar főváros gazdagon el van látva tanító- és tanítónőképző-intézetekkel; hármat az állam tart fenn, s három felekezeti jellegü. Az ország legnagyobb tanítóképző-intézete az, melynek hatalmas épülete terjedelmes kertjével, mellékházaival és szőlőmívelési telepével a budai oldalon, a Krisztinavárosban terül el. Az intézetben 120 növendék számára korszerűen berendezett internátus áll fenn.” A szerző hangsúlyozta: ,ily fejlődés természetesen nem képzelhető tetemes költségű építkezések és házvételek nélkül” (Berzeviczy, 1893).

A Gyetyánffy által megszervezett, több képzési formát egyesítő budai Paedagogium nem bizonyult hosszú életűnek, 1904-től önállósult a polgári iskolai tanítóképzés, 1909-től az Apponyi Kollégiumhoz került a tanítóképző-intézeti tanárok képzése, a Budai Képző így a népiskolai tanítóképzés központi műhelye maradt (Tóth, 1991, 1992, 1992a). Gyertyánffy után az első magyar játékgyüjtemény öszszeállításával hírnevet szerző Kiss Árontól, aki 1904-ben a polgári iskolai tanítóképző igazgatója lett, Baló József vette át a tanítóképző igazgatását. Tizenkét esztendős vezetői működésének pillanatait számos kép és dokumentum őrzi. Müködésének időszakában, 1911-ben költözhetett a képző saját, máig otthonául szolgáló épületébe, ennek emléke „kőbe vésve” maradt fenn.

Az építkezéshez állami támogatást szerezni a század elején sem volt egyszerü, ezt mi sem mutatja jobban, mint az a hatalmas fekete márványtábla, ami ma is áll a képző bejáratánál, a hála kifejezéseképpen feltüntetve a király, a vezető állami és fővárosi tisztségviselők neveit, emléket állít a képző igazgatójának és tantestületének és persze a tervezőnek is. A Mozdony utcai új épület a képzés igényeinek megfelelően készült, benne helyet kapott a gyakorlóiskola és az internátus, felszerelték könyvtárral, szertárakkal, a kupolában bemutató csillagvizsgálót is létesítettek. A házat több mint kétezer négyzetméteres kert övezte, amelyben szőlő és gyümölcsfák, konyha- és virágoskert, sőt még méhészet is szolgálta az Eötvös-tör- 
vényben körvonalazott, sokoldalú, gyakorlatias tanítóképzést, amint erről a történeti előzményeket felsorakoztató évkönyvek számot adtak (Padányi, 1940, 1941).

Az első világháború súlyos törést okozott a Budai Képző életében. A Budapesti Állami Tanítóképző Intézeti Iskolatársak Egyesülete 1934-ben emlékművet állított a háborúban katonai szolgálatot teljesítő, a fronton elesett harmincnégy képzős áldozatnak. A Tanácsköztársaság uralmának idején, 1919 júliusában a képző épületét kisajátították, pincéjében a különítményesek összeesküvéssel megvádolt csendőrtiszteket végeztek ki. A tetteseket a proletárdiktatúra leverését követően halálra ítélték. A tanítóképzőt házából kiűző, szellemiségével ellentétes, véres történésekre az emlékeztetett, hogy a Mozdony utca Fery Oszkár csendőr altábornagy nevét vette fel. 1921-ben a csendőrtisztek emlékét őrző márványtáblát helyeztek el a képző épületén, amit 1945-ben, a lebombázott épület helyreállítása során nem, csak 2011-ben állítottak újra (Donáth, 2012).

A második világháború sem kímélte a Budai Képzőt: az 1943-44. tanévi évkönyv öt korábbi növendék haláláról tesz említést, az összes képzős áldozatról azonban az évkönyvekben nincs adat. Az épületben 1944. április végétől német katonai kórházat rendeztek be, a többször megszakított tanév ezért május 5-én zárult. A harcok alatt a falak, a tető, a kupola is megsérült, az épület minden helyisége használhatatlanná vált (Padányi, 1943, 1944). A Mozdony, majd Fery Oszkár utcát a második világháború végén a Magyar Nemzeti Felkelés Felszabadító Bizottságához csatlakozott és ezért a hungarista Nemzeti Számonkérő Szék ítélete alapján - másik két katonatiszttel együtt - 1944 decemberében kivégzett Kiss János altábornagyról nevezték el, emléküket a képző épületén márványtábla őrzi.

A háború után a helyreállításban a növendékek és tanáraik is részt vettek, a tanítás csakhamar újraindult, az épület restaurációja azonban még évekig folyt. A munkálatok elsősorban a müködtetéshez elengedhetetlen területekre irányultak, így az emlékművek, emléktáblák, jelképek beszédes sorsára csak évtizedekkel később derült fény. Hosszú évtizedek elteltével került ismét látható helyre az építést megörökítő márványtábla, valamint az első világháború képzős áldozatainak emlékműve. A tetőre 1945-ben kitűzött vörös csillag ellenben a hatvanas évek felújítási munkáit követően nem kerül vissza.

1968-ban óvóképzés indult Budán, a hetvenes években a tanítóképzés létszáma is jelentősen nőtt, ezért a képző egy pesti iskolaépület kapott, amely harminc évig szolgálta a tanító- és óvóképzést. Ezt az épületet 2007-ben értékesítette az egye- 
tem. 1975-ben új gyakorló óvoda épült - ezt 2006-ban az egyetem szintén értékesítette, ma bérelt helyen működik a gyakorló óvoda.

Jelentős fejlődést eredményezett a régi épülettel összekötött, új gyakorlóiskola átadása 1982-ben, majd pedig 1990-ben az előadókkal, kiállítási terekkel és laboratóriummal felszerelt, új épületszárny birtokbavétele. Szükség is volt a fejlesztésekre, mert a hetvenes évek végétől kezdődően általában kétezer fős, némelykor annál is nagyobb létszámú hallgatóság tanulási feltételeit biztosítani kellett. A technikai korszerűsítéssel - az informatikai hálózat kiépítését is ideértve - ugyan az intézmény igyekezett lépést tartani, jelentősebb, az épület homlokzatát, szigetelését is érintő felújításra azonban csak 2016-tól került sor. A korábban nagy játszóés testedző teret, konyhakertet, gyümölcsöst, szőlőt is magába foglaló kert és udvar fokozatos zsugorodásának oka az említett, szükséges bővítések területigénye mellett a szomszédos telekre épült, politikai célokat szolgáló épület, és az annak helyébe emelt, terebélyes irodaház volt. A hatalmas hársfa és a megmaradt kert virágágyásai még ma is megjelenítik a tanítóképzés hagyományait tovább éltető természetszeretetet.

\section{Aetas semper aportat aliquid novi}

A Budai Képző fényképeinek gyűjteményéből is látszik, hogy tanítóképzés 21. századi megújulásának egyik legnagyobb horderejű tényezője a digitalizáció, amely a képző szerény technikai adottságai mellett is jelentősen átalakította a képzés folyamatát, ennek látható jele, hogy az egyetem mindegyik, oktatásra használt terme el van látva számítógéppel és projektorral, elősegítve a gyorsabb kommunikációt és hatékonyabb oktatást.

A 21. századi fejlődést és nyitottságot igazolják a külföldi társintézményekből érkező vendégek, fényképeik dokumentálják a jelenlétet a képzésben, a hallgatók és oktatók egyre növekvő mértékủ részvétele a nemzetközi felsőoktatásban, ami nem kis részben az Európai Unió legsikeresebb programjának, a külföldi tanulás ösztöndíjakkal való támogatásának köszönhető.

A Budai Képző a kezdetektől fontosnak tartotta a nemzetközi tapasztalatok gyưjtését, az első idők meghatározó pedagógusai állami támogatással szereztek tapasztalatokat svájci, német, francia egyetemeken. Az évkönyvekből kirajzolódik, hogy minden korszakban érkeztek más országokból vendégek, a képzős tanárok is gyakran vettek részt külföldi szakmai utakon. Képek is tanúsítják, hogy a Budai Képző a múlt század második felében sem csak az akkor „testvérinek” neve- 
zett országokkal, nem is csupán a nyugati világ baloldali mozgalmaival ápolt kapcsolatokat (arról persze az évkönyvek nem adnak számot, hogy mennyire ellenőrizte a hatalom ezeket az utakat). Példaként az 1970 és 1974 közötti időszakról beszámoló évkönyvből idézünk:

„Együttműködési szerződésünk ugyan nincs külföldi intézménnyel, de Budapesten lévén intézetünk, gyakran kerestek fel bennünket külföldi delegációk, kutatók, a pedagógusképzéssel foglalkozó szakemberek. A pedagógusképzés gyakorlatának megismerése, kutatóintézetekkel való konzultáció, kutatási partnerek megismerése céljából nyújtották be oktatóink pályázatukat külföldi kiküldetés elnyerése céljából." Közülük többen 1-4 hetes kiküldetéssel utazhattak például Angliába, Finnországba, Belgiumba is (Adamikné et al, 1974, p. 21-22). A nyolcvanas években már hallgatók is nagyobb számban utazhattak külföldre, a tanárok közül például Adamik Tamásné 1986-87-ben egy évig az Egyesült Államokban oktatott, állítható tehát, hogy a Budai Képző ma hatvannál több partnerintézménnyel szerződésben rögzített együttműködése nem előzmények nélküli. Hagyományait követve fejleszti a nemzetiségi német tanító- és óvóképzést, mellette szerb nemzetiségi képzést is folytat. A Budai Képző 2019-től a külföldi és hazai hallgatókat is fogadó angol nyelvủ óvóképzést indított, ezzel megerősítve a nemzetközi felsőoktatás áramába való bekapcsolódását.

A művészetek jellegük folytán eleve „nemzetköziek”, jelentős szervezeteik: az EAS (European Assotiation for Music in Schools), a Music-Europe (MUS-e) és az INSEA (The International Society for Education Through Art) munkájában a Budai Képző oktatói évtizedek óta szerepet vállalnak.

A pezsgő kulturális élet minden tanítóképző valamennyi korszakának jellemzője volt, ezt a hagyományt a képzők elkötelezettséggel folytatják. A Budai Képző képgyüjteményében az ünnepi események, évfordulók, megemlékezések, kulturális rendezvények anyaga a leggazdagabb. Az ének-zene, valamint a képzőművészet a kezdetektől meghatározó része volt és maradt a tanítóképzésnek, tudományos értekezések bizonyítják ennek jelentőségét a gyerekek személyiségének, alkotókedvének kibontakoztatásában. A jelöltek öntevékeny körei mellett a kitűnő kórusok, valamint a maga nemében egyedülálló, 1981-ben alakult és azóta folyamatosan új bemutatókkal hazai és nemzetközi közönsége elé lépő Zenés Színpad említése akkor sem mellőzhető, ha tudjuk, hogy előkészületben vannak a tárgykörről készült alaposabb kiadványok. Magától értetődik tehát, hogy a Budai Képző ismert művésztanárok sorával büszkélkedhet. Bálványos Huba grafikusművész 
alkotóként és pedagógusként is meghatározó szerepet töltött be a hazai szakmai közéletben, munkásságáról képek sokasága tanúskodik, a nevét viselő műhely folytatja az általa megalapozott tevékenységet. A képző folyosóit, tereit a folyamatosan frissített oktatói, hallgatói és gyerekalkotásokból összeállított kiállítások teszik vizuálisan is inspiratívvá.

A testnevelés és sport a tanítóképzésnek szintén alapvető része, a jelöltek sportélete, egyéni és csoportos teljesítményeik felsorakoztatása sem mellőzhető az emlékezés során, az eredményekről, a hagyományokról és szerves folytatásukról a készülő kiadványok adnak képet.

A Budai Képző fennmaradását, a tanítóképzésben mindvégig betöltött kezdeményező szerepét annak is köszönheti, hogy a szakmai tudást, tiszteletre méltó tanárainak munkáját a hatalmi viszonyok változásai közepette is megbecsülte. Szerepe lehet a képzőnek talán abban is, hogy a hazai tanítóképzés összességében megfelelő teljesítményt nyújt: a negyedikes magyar diákok a 21. századi nemzetközi mérések szerint jó eredményeket érnek el a szövegértés, a természettudományok és a matematika terén (Balázsi et al, 2017; Szalay et al, 2016). ${ }^{5}$ A jubileum sem ad felmentést ugyanakkor a feladatok számbavétele alól. A sok javítanivaló közül az alapfokú iskoláztatásnak egyik legsúlyosabb problémája volt és maradt az iskolás gyerekek közötti különbségek értő kezelése az iskola mindennapjaiban. Igaz, ma az egy tanító gondjaira bízott gyerekek számának felső határa már nem 80, ahogyan az Eötvös-törvény előírta, még csak nem is 50 és 78 közötti, mint ami az 1900. évi népszámlálás adataiból kitűnik, sőt bizonyos statisztikák szerint az ezredforduló után ez a létszám nemzetközi összehasonlításban kifejezetten alacsony. Hiába azonban a tetszetős adat, mert az egyéni gondoskodásra felkészített, az egyes gyerekek (különleges) szükségleteinek megfelelő támogatást biztosító szakemberek folyamatos jelenléte nélkül az együttnevelés eredményei nem tekinthetők kielégítőnek, az alapfokú oktatás rendszere ezért nem szolgálja az elvárható mértékben a jövőt.

Az emlékőrző pillanatképek zárásaként álljon itt egy idézet Ancsel Éva akadémikustól, aki 1960-tól 1968-ig volt a Budai Képző tanára:

„A nevelésnek terve van, s persze úgy tünik, hogy ezt akkor lenne a legkönynyebb megvalósítani, ha a pedagógusoknak egynemü 'nyersanyaggal' lenne dolguk. Aki nem tud letenni az egyneműség amúgy sem vonzó illúziójáról, annak

${ }^{5}$ Az IEA (International Association for the Evaluation of Educational Achievement) 1961-ben, oktatásku-
tatók kezdeményezésére jött létre, tagjai 50 ország kutatóintézetei, munkájának része az egyes országok
iskoláztatásának eredményességét feltérképezni, ilyen, ötévente ismételt vizsgálatok a PIRLS és a TIMSS. 
számára a gyerekek személyisége nem más, mint zavaró körülmény, lenyesni való, eltüntetésre váró kinövés, a modell utáni formázás akadálya. [...] Valahányszor azt hallom, hogy elő kell segíteni a fiatalok konfliktusmentes beilleszkedését a társadalomba - s ezt sokszor hallom - újra és újra azt kérdezem, ha ez netán sikerülne, hogyan fog ebben az esetben társadalmunk előbbre haladni?” (Ancsel, 1976, p. $82,83)$.

\section{Irodalom}

A magyar királyi állami elemi tanítóképezdék tanterve. Kiadatott a vallás- és közoktatásügyi m. kir. minister 1882-dik évi február hó 6-án 8998. sz. a. kelt rendeletéből. In Népoktatási törvények, tantervek és vizsgálati szabályrendeletek (1884), Athenaeum. 224.

Adamik Tamásné Dr. \& Bollók Jánosné Dr. \& Fodor József (1974). A Budapesti Tanítóképző Intézet Évkönyve.

Ancsel, É. (1976). Töredékek az emberi teljességről. Magvető Kiadó.

Balázsi, I. \& Balkányi, P. \& Vadász, Cs. (2017). PIRLS 2016. Összefoglaló jelentés a 4. évfolyamos tanulók eredményeiról. Oktatási Hivatal.

Belting, H. (2008). Kép, médium, test: az ikonológia új megközelítésben. Apertúra IV/4.

Berzeviczy, A. (1893). Budapest. Közművelődési intézetek. Budapest iskolái. In: $A z$ Osztrák-Magyar Monarchia írásban és képben. IX. (1886-1901).

https://www.tankonyvtar.hu/hu/tartalom/tkt/osztrak-magyar/ch15s06.html (2019. 05.10)

Bollókné Panyik, I. \& Hunyady Györgyné (2003). A tanítóképzés az integrált felsőoktatásban. Új Pedagógiai Szemle 53(7-8), pp. 4-16.

Bollókné Panyik, I. \& Kelemen, E. (1996). A Budapesti Tanítóképző Főiskola története. In Cseh, S. (Ed) Tanitó- és óvóképző föiskolák az új évezred küszöbén. pp. 29-36

Donáth, P. (1998). Iskola és politika. Az állami német nemzetiségi tanítóképzés magyarországi történetéhez 1919-1944. Trezor Kiadó.

https://mek.oszk.hu/05 100/05 108/

Donáth, P. (2008). A magyar múvelődés és a tanitóképzés történetéből, 1868-1958. Trezor Kiadó. https://mek.oszk.hu/08 200/08 254/

Donáth, P. (2012). A Cserny-különítmény rémtettei ... In Donáth, P. (Ed): Sorsfordító mozzanatok a magyarországi kisgyermekkori nevelóképzés, a Budapesti Tanitóképző Főiskola, az ELTE TÓK és épülete történetéből. Trezor Kiadó. pp. 144-254.

Donáth, P. (2015). Tanítói, tanári viták a magyarországi tanítók társadalmi küldetéséről, helyzetük javításáról, a tanítóképzés korszerűsítéséről, felsőfokúvá té- 
teléről-1890-1905. In Donáth, P. (Ed) Filozófia - művelődés - történet. Trezor Kiadó. pp. 223-388. https://mek.oszk.hu/14 800/14882/

Ember, M. (1998). Budáról át Pestre. Mozaikok az Erzsébet Nőiskola történetéből. Barátság 1998(5/6), pp. 2324-2326.

Eötvös, J. (1977). Vallomások és gondolatok. Bényei, M. (Ed) Magyar Helikon.

Ferenczi, Z. (1903). Báró Eötvös fózsef 1813-1871. Magyar Történelmi Társulat Athenaeum. http://mek.oszk.hu/05 700/05 708/ (2019. máj. 10.)

Hunyady, Gyné. (2012). Rendszerváltás a tanítóképzésben. Iskolakultúra, 22(1) pp. 36-49.

Kelemen, E. (1999): Bevezetés. In Csíkvári et al. A Budapesti Tanitóképző Főiskola évkönyve 1994-1999. Trezor Kiadó. pp. 7-17.

Kelemen, E. (2004). Pedagógusszervezetek és -mozgalmak Magyarországon a 19. században. Iskolakultúra, 2004 (6-7), pp. 146-155.

Kelemen, E. (2007). A tanító a történelem sodrában. Iskolakultúra könyvek 32 . sz. https://mek.oszk.hu/05 200/05 223/

Kelemen, E. (2012). A Budapesti Tanítóképző Főiskolától az ELTE Tanító- és Óvóképző Főiskolai Karig. In Donáth, P. (Ed) Sorsfordító mozzanatok a magyarországi kisgyermekkori nevelőképzés, a Budapesti Tanitóképző Főiskola, az ELTE TÓK és épülete történetéből. Trezor Kiadó. pp. 70-81.

Kiss, Á. (1886). Őfelsége a király a budapesti I. ker. tanítóképezdében. Néptanitók Lapja, XIX/38.

Kováts, G. \& Temesi, J. (2018). Összefoglaló megállapítások. In Kováts, G. \& Temesi, J. (Ed) A magyar felsőoktatás egy évtizede 2008-2017. Corvinus.

Márkus, É. \& M. Pintér T. (2019). A 200 éves német nyelvű tanítóképzés története Magyarországon. Pedagógusképzés. Pedagógusképzők Folyóirata 18(46), 78-108.

Márkus, É. \& Radvai, T. (2017). Die Padagoginnenausbildung für Kindergarten und Primaschulen der deutschen Minderheit in Ungarn an der ELTE TÓK. In Philipp, H. \& Ströbel, A. (Eds.) Deutsch in Mittel-, Ost- und Südeuropa: Geschichtliche Grundlagen und aktuelle Einbettung. Verlag Friedrich Pustet, Regensburg. pp. 615-634.

Mesterházy, J. (1943) Emlékiratunk és anyagi ügyeink. Magyar Tanitóképző, 1943(9) A tanítóképző-intézeti tanárok országos egyesületének folyóirata. 1943. szeptember, pp. 229-230.

Nábrádi, I. (1970). A Budapesti Tanitóképző Intézet jubileumi évkönyve: 1968-1970.

Nagy, M. (1881). Gyertyánffy István és a Budai Tanítóképezde. Vasárnapi Újság,1881. június 12. XXVIII/24. pp. 375-377. 
Padányi-Frank, A. Dr. (1940). A Magyar Királyi Állami Líceum és Tanitóképző Intézet évkönyve az 1939-40. tanévröl.

Padányi-Frank, A. Dr. (1941). A Magyar Királyi Állami Líceum és Tanitóképző Intézet évkönyve az 1940-41. tanévről.

Padányi-Frank, A. Dr. (1943): A Magyar Királyi Állami Líceum és Tanitóképző Intézet évkönyve az 1942-43. tanévröl.

Padányi-Frank, A. Dr. (1944): A Magyar Királyi Állami Líceum és Tanítóképző Intézet évkönyve az 1943-44. tanévről.

Paksi, B. et al. (2015). Pedagógus-pálya-motiváció. Egy kutatás eredményei. Oktatási Hivatal.

Panyik Ilona (1991). A Budapesti Tanitóképző Főiskola. Tankönyvkiadó.

Polónyi, I. (2018). A hazai felsőoktatás elmúlt 10 évének néhány gazdasági jellemzője. In Kováts, G. \& Temesi, J. (Eds.) A magyar felsőoktatás egy évtizede 20082017. Corvinus.

Radó, V. (1892). Tanítóképzésünkről. Magyar Paedagogia. 1892 (1), p. 21.

Szakál, J. (1934). A magyar tanítóképzés története. Hollósy János Könyvnyomtató. (Kiadatott a vallás- és közoktatásügyi m. kir. minister 1882-dik évi február hó 6-án 8998. sz. a. kelt rendeletéből)

Szalay, B. et al. (2016). TIMSS 2015. Összefoglaló jelentés. Oktatási Hivatal.

Tavasi, L. (Ed.) (1948). Nevelési Emléklapok. Hatodik Füzet.

Tóth, G. (1991). A magyarországi tanítóképző-intézeti tanárképzés kezdetei. Pedagógusképzés, (1)

Tóth, G. (1992). A tanítóképző-intézeti tanárképzés Budapesten. Pedagógusképzés, (1)

Tóth, G. (1992a). Az Apponyi Kollégium hallgatói (1906-1949). Magyar Pedagógia. 1992 (4) pp. 285-307.

Visy, B. (2017). Fénykép és szöveg, fénykép az irodalomban - elméleti közelítések. Helikon 2017 (4) pp. 463-500. 


\section{Historical snapshots from the $\mathbf{1 5 0}$ years of the Hungarian elementary school teacher education - Memories from the history of the Hungarian institution: the Budai Képző}

At the initiative of Minister of Religion and Education, József Eötvös, started operating in the autumn of 1869 the first Hungarian state teacher education institute: the "College of Buda", the predecessor institution of the Faculty Primary and Pre-School Education of ELTE.

The documents, albums, yearbooks, press reports, photographs collected during the 150 years of the College in Buda activities have captured festive moments, eventfull everyday life, eminent teachers and typical locations.

A review of old newspaper pages, manuscripts, printed materials and many photographs seems to confirm that changes in slogans, externalities, and symbols have not changed the basic principles of education that expressed by József Eötvös.

In the midst of changing power relations, the College in Buda has always honoured his traditions, the work of his knowledgeable teachers, it has hosted arts, culture, and it has been at the forefront of renewing teacher education.

The quality of Hungarian primary-school teacher education is demonstrated by the fact that in fourth graders perform well in international surveys of reading literacy repeated in the every five years since 2001, similarly to mathematical and science surveys that are repeated every four years.

Keywords: State Primary School Teacher Education, College in Buda, fózsef Eötvös, memorials, traditions, renewal, appreciation 